\title{
Dead or Alive? Teacher Students' Perception of Invasive Alien Animal Species and Attitudes towards their Management
}

\author{
Martin Remmele ${ }^{1 *}$, Petra Lindemann-Matthies ${ }^{1}$ \\ ${ }^{1}$ Karlsruhe University of Education, GERMANY
}

Received 18 July 2019 - Accepted 5 December 2019

\begin{abstract}
This study investigated the perception of 13 invasive alien animal species (IAAS) by 220 teacher students and their attitudes towards species management, either with or without prior information about the IAAS presented. In a first questionnaire, the IAAS (eight vertebrates, five invertebrates) were presented as photographs and their invasive status was not revealed. In a second questionnaire, one half of the participants received information about the invasive character of the species, the other half did not. Then, attitudes of both groups towards various management options were assessed. Mammals such as grey squirrel, raccoon and raccoon dog were considered most beautiful and wanted, but the harlequin ladybird, an insect, was also considered attractive. Participants who had received information about the invasive character of the species presented were more in favor of eradication and partial removal than those who had not, but still less willing to remove mammals and birds than arthropods. The present results highlight the importance of information on IAAS so that teacher students can understand the reasons for certain types of management. As multipliers of tomorrow, they might be better prepared for teaching this topic in school.
\end{abstract}

Keywords: management, public attitudes, public perception, invasive alien animal species

\section{INTRODUCTION}

Biological invasions by non-native or 'alien' species are major drivers of environmental change (Early et al., 2016; MEA, 2005; Simberloff et al., 2013; Vilà et al., 2011), but may vary across regions and taxa, and change over time (Bellard, Leroy, Thuiller, Rysman, \& Courchamp, 2016). They occur in all taxonomic groups and can affect all types of ecosystems (CBD, 2009). Invasive alien species (IAS) can be defined as species which establish outside their native ranges and, once established, spread extensively, causing significant harm to biodiversity, ecosystem processes and human well-being in the invaded regions (Hulme, Pyšek, Jarošík, Pergl, Schaffner, \& Vilà, 2013; Vilà et al., 2011). The quantity of unintentionally introduced IAS is related to the overall level of international trade of a country; the pet and horticultural trade is currently a leading vector of deliberate terrestrial IAS introductions (Bellard et al., 2016; Hulme et al., 2018; Keller, Geist, Jeschke, \& Kühn, 2011). Both trades are increasing globally, and are poorly regulated (Hulme et al., 2018; Humair, Humair, Kuhn, \& Kueffer, 2015; Keller \& Perrings, 2011; Smith, Behrens, Schloegel, Marano, Burgiel, \& Daszak, 2009). As humans take an active part in the introduction, establishment and spread of IAS, it is necessary to understand their knowledge of and attitudes towards the use and management of invasive species (Bardsley \& EdwardsJones, 2007; Shackleton et al., 2019). Increased awareness among the general public of the threats posed by invasive species might lead to decisions and actions that may help to prevent their spread. This applies not only to adults but also to children as decision makers of tomorrow and, of course, to their teachers as they influence students' knowledge and attitudes. But what do future teachers know about invasive species, and which management decisions do they support? The present study aims to answer these questions.

In Europe, there are over 12,000 alien species, $15 \%$ of which are invasive (http://www.europe-aliens.org/ default.do). In terms of IAS, most of the aquatics and terrestrial invertebrates and disease causing organisms 


\section{Contribution to the literature}

- Teacher students perceive invasive alien species as native and desired.

- Information on invasive alien animal species increases teacher students' support for management action.

are accidental arrivals, whereas most of the vertebrates and plants are introduced deliberately. As they all cause substantial damage, prevention, control and eradication measures are needed. Designing policies which prevent the introduction and release of IAS, and the management of species already established have become priority goals in many European countries (European Commission, 2017). As IAS can easily spread across borders, the EU has recently adopted a new law (Regulation (EU) 1143/2014) to tackle the problem in a coordinated, joint effort across all Member States. The IAS Regulation also implements the EU Biodiversity Strategy to 2020 which sets a specific target to combat the threat of invasive alien species in order to halt the loss of biodiversity and ecosystem services (European Commission, 2017).

The public's support can be a key to success or failure of management measures regarding IAS (Bertolino \& Genovesi, 2003; Bremner \& Park, 2007; Crowley, Hinchliffe, \& McDonald, 2019; Shackleton et al., 2019). However, laypersons' knowledge of IAS may be very limited (Lindemann-Matthies, 2016; Waliczek, Williamson, \& Oxley, 2017). Moreover, the discussion about IAS management and species conservation often neglects values which people attach to certain organisms (Estévez, Anderson, Pizarro, \& Burgman, 2015; Heink \& Jax, 2014; Lindemann-Matthies, 2016; Lute \& Attari, 2016; Shackleton et al., 2019). When, for instance, in a UK-wide national survey the attitudes of the public ( $\mathrm{n}=$ 3758 ) to grey squirrels and their control were investigated, respondents had little knowledge of the negative impacts of the species (Dunn, Marzano, Forster, \& Gill, 2018). Instead, they appreciated the presence of grey squirrels and found control methods proposed by wildlife professionals hardly acceptable. This example shows that perceptions of laypersons on species conservation might strongly differ from those of conservationists and natural resource managers, especially when the killing of charismatic mammals is discussed (Lundberg, 2010; Minteer \& Collins, 2005; Shackleton et al., 2019).

Attributes of animals can strongly influence people's conservation actions (e.g., Colléony, Clayton, Couvet, Saint Jalme, \& Prévot, 2016). People prefer charismatic animals, i.e., animals with popular appeal, which are similar to humans in appearance and behavior (Albert, Luque, \& Courchamp, 2018; Colléony et al., 2016; Lindemann-Matthies, 2005; Morris \& Morris, 1966; Prokop \& Fančovičová, 2013; Prokop \& Randler, 2007), and tend to avoid invertebrates like insects and spiders that are morphologically and behaviorally unlike humans (Morris \& Morris, 1965; Kellert, 1996; Lorimer, 2007; Prokop \& Randler, 2018; Wagler \& Wagler, 2011). In consequence, invasive species management targeting charismatic wildlife can be highly controversial (Crowley et al., 2019; Kueffer \& Kull, 2017; Shackleton et al., 2019).

Education, either in formal or informal settings, could be one way to inform laypersons about IAS and their potential harm to biological diversity, ecosystem functioning, socio-economic values, and human health in the invaded regions. It could also be one way to promote a differentiated understanding of IAS management. However, few studies have investigated so far how teachers or teacher students perceive IAS, and which management measures they support. It is also hardly known if laypersons (teachers included), who have been informed about the harmfulness of an invasive species, respond differently to appropriate management measures than those who have not previously been informed (but see Novoa, DehnenSchmutz, \& Vimercati, 2017; Waliczek et al., 2017). After laypersons in South Africa and in the UK had been informed about the invasive status and negative impact of certain IAS targeted for management, support for the chosen management actions increased (Novoa et al., 2017). A similar result was found for college students who underestimated the negative impact of invasive species, but were more in favor of IAS management after receiving class instructions (Waliczek et al., 2017).

The present study investigates the perception of 13 invasive alien animal species by 220 primary and secondary teacher students in Germany, and their attitudes towards species management, either with or without prior information about the respective species. Main objectives were to investigate teacher students' (1) characterization of the 13 IAAS shown on paper, (2) ability to identify them, (3) general attitudes towards the management of IAAS, and (4) specific attitudes towards management measures for each of the IAAS presented, either with or without prior information about the impact of the respective species.

It was also investigated whether teacher students' perception of IAAS and attitudes towards certain types of management were related to age, gender, place of living, and study subject (biology vs. other subjects). Cultural factors such as age, gender, and expertise of a person (here: training in biology) are important determinants of human-nature interactions (e.g., Bourassa, 1991). Moreover, a person's attachment to a place might influence his or her attitude towards IAAS management (Shackleton et al., 2019). City-dwellers, for 
instance, might be more in favor of rose-ringed parakeets, which can typically be found in urban parks, than people who live in the countryside.

\section{METHODS}

\section{Data Collection}

Data were collected at the University of Education in Karlsruhe, Germany. Randomly selected teacher students $(n=220)$ were asked, always in a similar way, to participate in a study about animals. If they agreed, and almost all of them did so, they received two questionnaires, one after the other. Data collection exercises required approximately 20 minutes of time, and anonymity was guaranteed to the participants. Participants (82\% women) were between 19 and 33 years old (mean age $=24$ years, $\mathrm{SD}=2.5$ ), and $61 \%$ were students of biology.

\section{Questionnaire Approach}

The present survey consisted of two questionnaires (see Appendix A), which were printed on two separate sheets of paper to avoid influences of the second questionnaire, in which information about IAAS was provided, on the first one. Participants were instructed to ask for the second questionnaire after finishing the first one.

The first questionnaire investigated teacher students' perception of 13 IAAS and their skills to identify these species (objectives 1 and 2). Overall, eight vertebrates (four mammals, two birds, one amphibian, and one fish) and five invertebrates (three insects, one spider, and one crustacean) were presented. The following species were included in the survey (brief information on each species in Appendix C): grey squirrel (Sciurus carolinensis), raccoon (Procyon lotor), muskrat (Ondatra zibethicus), raccoon dog (Nyctereutes procyonides), rose-ringed parakeet (Psittacula krameri), Egyptian goose (Alopochen aegyptiacus), American bullfrog (Lithobates catesbeiana), stone moroko (Pseudorasbora parva), harlequin ladybird (Harmonia axyridis), Asian hornet (Vespa velutina), Asian tiger mosquito (Aedes albopictus), varroa mite (Varroa destructor), and Chinese mitten crab (Eriocheir sinensis).

Species were chosen by popularity (Procyon lotor, Nyctereutes procyonides, Sciurus carolinensis, Psittacula krameri, Alopochen aegyptiacus and Harmonia axyridis might be perceived as attractive), aversion (Ondatra zibethicus, Lithobates catesbeiana, Vespa velutina, Aedes albopictus, Eriocheir sinensis, and Varroa destructor might be perceived as disgusting), ecological and socioeconomic impact (Sciurus carolinensis, Aedes albopictus and Eriocheir sinensis are among the world's 100 worst invasive alien species [http://www.iucngisd.org/gisd/ 100_worst.php] and nine species are of Union concern [http:/ / ec.europa.eu/environment/nature/invasiveali en/list/index_en.htm]), and threats to human health (Procyon lotor and Aedes albopictus).

To reduce the number of species a participant had to characterize and identify, two questionnaire versions were provided. The first version included six IAAS (Procyon lotor, Sciurus carolinensis, Psittacula krameri, Harmonia axyridis, Lithobates catesbeiana, and Varroa destructor) and was shown to 118 teacher students. The second one included seven IAAS (Nyctereutes procyonides, Ondatra zibethicus, Alopochen aegyptiacus, Pseudorasbora parva, Vespa velutina, Aedes albopictus, and Eriocheir sinensis) and was shown to 102 teacher students. Otherwise, both questionnaire versions were completely identical.

The 13 IAAS were presented as photographs and their invasive status was not revealed. All photographs were in color and of high-resolution quality. Typical features of the species such as color and patterns of fur and feathers were clearly visible. Each species had to be characterized by five opposing attributes (uglybeautiful, extraordinary-ordinary, exotic-indigenous, unfamiliar-familiar, unwanted-wanted) on 7-step scales (e.g., very ugly, ugly, rather ugly, neither/nor, rather beautiful, beautiful, very beautiful). These characteristics covered a spectrum of relevant attributes used in the discussion about IAS and in previous research (e.g., Fischer \& van der Wal, 2007; Lindemann-Matthies, 2016). After the characterization exercise, participants had to identify as many species as they could and write down their common names. An animal was regarded as correctly identified if its name was provided at the species level or, in few cases, at the genus level (i.e., raccoon, muskrat, and raccoon dog). For instance, the answer "ladybird" for Harmonia axyridis would have been considered wrong as this would not clearly identify the invasive species.

The second questionnaire investigated teacher students' general attitudes towards different types of management (objective 3). A short introduction provided information about IAAS and also clarified that all species shown in the first questionnaire were invasive (see Appendix A). Participants had to choose among four different types of management (no intervention, no removal of aesthetically pleasing animals, but removal of less appealing ones, removal of only those invasive animals that provoke serious problems and costs, removal of all invasive animals in order to conserve unique habitats and species) to find the one type of management they considered most suitable. To investigate whether the choice of a certain management type depends on the species involved and on knowledge about the harm these species might cause (objective 4), all pictures were shown again. However, in half of the questionnaires, a brief portrait of each of the IAAS used in the picture test was also included (see Appendix B). In the resulting four versions of the second questionnaire (picture set 1 and 2, both either with or without 


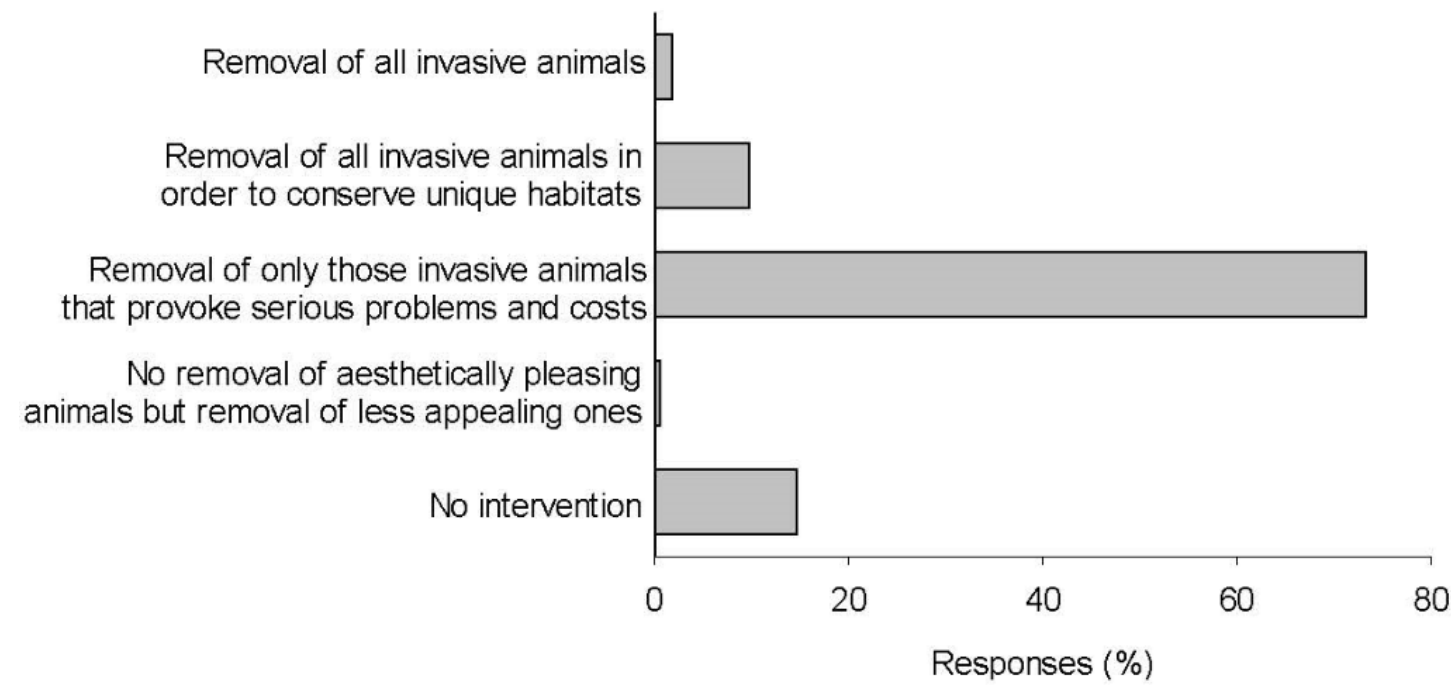

Figure 1. Preference for certain types of management (questionnaire 2, item 4). Teacher students $(n=220)$ had to choose among four management types the one they considered most suitable

information), participants had to select among three types of management (no intervention, partial removal of populations, eradication) the one they considered most fitting.

Finally, participants were asked about their age, sex, and place of living, i.e., the place where they had spent most of their lives so far (large city with more than 100,000 inhabitants; medium-sized city with 50,000100,000 inhabitants; small city with less than 50,000 inhabitants; rural area). Moreover, they were asked about their study subject (biology, other subjects). It should be noted that biology students at Karlsruhe University of Education do not receive special training in invasion biology. However, we assumed that they might be more interested in IAAS and thus also more knowledgeable about the species depicted than students of other subjects.

\section{Data Analysis}

Linear regressions were used to test for a relationship between the number of IAAS correctly identified and teacher students' age, sex, place of living, study subject, and questionnaire version. The number of IAAS was square-root transformed prior to analysis to obtain normally distributed residuals. The final minimum adequate models were obtained by backward elimination of non-significant $(P>0.05)$ variables. As this type of analysis does not allow strong correlations between explanatory variables $(r>0.35)$, Pearson correlations between binomial and metric explanatory variables were tested first (Crawley, 2005). However, none of the explanatory variables were significantly correlated with each other (all $r<0.17$; all $P>0.182$ ). The following variables and factors were initially included in the models: age, sex, rurality (1: large city to 4: rural area), study subject (biology or not), and questionnaire version (different IAAS).
Ordinal regression was used to test for a relationship between the socio-demographic variables and participants' attitudes towards certain types of management (as outlined in Figure 1). The four different types were reduced to three, i.e., no intervention, partial intervention (combination of answers "removal of IASP that provoke serious problems and costs" and "removal of aesthetically less appealing ones") and total removal of IAPS, and treated as an ordered dependent variable (from low to high intervention intensity). The following variables and factors were initially included in the model: age, sex, rurality, study subject, and "taxonomic knowledge" (number of species correctly identified).

Chi-squared test were used to investigate whether teacher students, who had received information on the IAAS presented, differed in their preferred management option from students without such information. All analyses were carried out with SPSS for Windows 24.0.

\section{RESULTS}

\section{Characterization of Selected IAAS (Objective 1)}

Most IAAS were perceived as familiar and native. The grey squirrel (Sciurus carolinensis) was considered most beautiful and wanted, but also most ordinary, while the rose-ringed parakeet (Psittacula krameri) and the Chinese mitten crab (Eriocheir sinensis) scored high on the extraordinary scale (Table 1). However, in terms of aesthetic appeal, no clear pattern was found for the different taxonomic groups. Mammals such as grey squirrel (Sciurus carolinensis), raccoon (Procyon lotor) and raccoon dog (Nyctereutes procyonides) were considered most beautiful, but the harlequin ladybird (Harmonia axyridis), an insect, was also among the most attractive species (see Table 1). The rose-ringed parakeet (Psittacula krameri) was also perceived as beautiful, while the other bird species, the Egyptian goose (Alopochen aegyptiacus), 
Table 1. Teacher students' characterization of 13 IAAS on seven-step scales (e.g., 1: very ugly, 2: ugly; 3: rather ugly; 4: neither ugly nor beautiful, 5: rather beautiful, 6: beautiful, 7: very beautiful). Species are sorted by perceived beauty

\begin{tabular}{|c|c|c|c|c|c|}
\hline \multirow[b]{2}{*}{ IAAS } & \multirow[b]{2}{*}{ ugly -beautiful } & \multicolumn{3}{|c|}{ Mean rating score $\pm 1 \mathrm{SE}$} & \multirow[b]{2}{*}{$\begin{array}{c}\text { unwanted } \\
\text { wanted }\end{array}$} \\
\hline & & $\begin{array}{c}\text { ordinary - } \\
\text { extraordinary }\end{array}$ & $\begin{array}{l}\text { exotic - } \\
\text { native }\end{array}$ & $\begin{array}{l}\text { unfamiliar - } \\
\text { familiar }\end{array}$ & \\
\hline Sciurus carolinensis & $6.3 \pm 0.08$ & $2.3 \pm 0.15$ & $6.0 \pm 0.15$ & $6.3 \pm 0.09$ & $5.6 \pm 0.13$ \\
\hline Procyon lotor & $5.8 \pm 0.09$ & $4.2 \pm 0.14$ & $4.4 \pm 0.15$ & $5.6 \pm 0.12$ & $4.3 \pm 0.13$ \\
\hline Nyctereutes procyonides & $5.7 \pm 0.12$ & $4.3 \pm 0.15$ & $4.0 \pm 0.17$ & $4.9 \pm 0.17$ & $4.0 \pm 0.17$ \\
\hline Psittacula krameri & $5.7 \pm 0.12$ & $4.9 \pm 0.14$ & $2.6 \pm 0.13$ & $4.2 \pm 0.15$ & $4.8 \pm 0.12$ \\
\hline Harmonia axyridis & $5.3 \pm 0.13$ & $2.3 \pm 0.15$ & $5.8 \pm 0.15$ & $6.2 \pm 0.13$ & $4.8 \pm 0.16$ \\
\hline Ondatra zibethicus & $4.7 \pm 0.12$ & $3.4 \pm 0.15$ & $5.1 \pm 0.15$ & $5.6 \pm 0.13$ & $4.6 \pm 0.15$ \\
\hline Pseudorasbora parva & $4.5 \pm 0.15$ & $2.7 \pm 0.13$ & $4.8 \pm 0.14$ & $4.8 \pm 0.17$ & $5.2 \pm 0.12$ \\
\hline Alopochen aegyptiacus & $4.3 \pm 0.16$ & $3.6 \pm 0.18$ & $5.1 \pm 0.15$ & $5.0 \pm 0.17$ & $4.9 \pm 0.13$ \\
\hline Vespa velutina & $4.1 \pm 0.15$ & $2.5 \pm 0.16$ & $5.3 \pm 0.16$ & $5.6 \pm 0.14$ & $3.3 \pm 0.22$ \\
\hline Lithobates catesbeiana & $3.5 \pm 0.13$ & $3.1 \pm 0.14$ & $4.9 \pm 0.15$ & $4.7 \pm 0.16$ & $4.2 \pm 0.12$ \\
\hline Eriocheir sinensis & $2.9 \pm 0.16$ & $4.5 \pm 0.18$ & $5.3 \pm 0.16$ & $5.6 \pm 0.14$ & $3.3 \pm 0.22$ \\
\hline Aedes albopictus & $2.0 \pm 0.14$ & $2.8 \pm 0.18$ & $4.3 \pm 0.21$ & $5.8 \pm 0.15$ & $1.6 \pm 0.13$ \\
\hline Varroa destructor & $1.7 \pm 0.09$ & $4.0 \pm 0.19$ & $3.2 \pm 0.15$ & $3.5 \pm 0.20$ & $2.3 \pm 0.11$ \\
\hline
\end{tabular}

received only a rather moderate rating. However, Asian tiger mosquito (Aedes albopictus), varroa mite (Varroa destructor) and Chinese mitten crab (Eriocheir sinensis) all invertebrates - were clearly on the ugly and unwanted side.

There was a positive correlation between perceived familiarity with a species and perceived nativeness (scores on the "unfamiliar-familiar" and "exotic-native" scale, all correlation coefficients between 0.230 and 0.738 , all $P$ between 0.021 and $<0.001$ ). If teacher students felt familiar with an IAAS, they considered it native.

For most IAAS, aesthetic appeal and desirability of a species (attributed scores on the "ugly-beautiful" and "unwanted-wanted" scale, respectively) were positively correlated (correlation coefficients between 0.213 and 0.501, all $P<0.035$ ). In case of raccoon (Procyon lotor), rose-ringed parakeet (Psittacula krameri) and Asian tiger mosquito (Aedes albopictus) the correlation was positive, but not significant at the 5\%-level $(P$ between 0.072 and 0.187).

Moreover, perceived nativeness and desirability of a species (scores on the "exotic-native" and "unwantedwanted" scale) were correlated. For grey squirrel (Sciurus carolinensis), raccoon (Procyon lotor), rose-ringed parakeet (Psittacula krameri), American bullfrog (Lithobates catesbeiana), stone moroko (Pseudorasbora parva), harlequin ladybird (Harmonia axyridis) and Chinese mitten crab (Eriocheir sinensis), the correlation was positive (correlation coefficients between 0.190 and $0.567, P$ between 0.041 and $<0.001$ ), while for the varroa mite (Varroa destructor), the correlation was negative (correlation coefficient $=0.432, P<0.001$ ).

\section{Identification of the 13 IAPS (Objective 2)}

About $31 \%$ of the teacher students could not correctly identify any of the IAAS shown on paper. A further $52 \%$ could at least identify one, $11 \%$ two, $5 \%$ three, and $1 \%$ four of the 13 species presented. Raccoon (Procyon lotor)
Table 2. Correctly identified IAAS at the genus or species level by teacher students $(n=220)$. Seven IAAS were shown to 119 and a further six to 101 persons. In square brackets: number of respondents

\begin{tabular}{lc}
\hline IAAS & $\begin{array}{c}\text { Correct } \\
\text { identifications } \\
(\mathbf{0})\end{array}$ \\
\hline Raccoon (Procyon lotor) & $94.1[119]$ \\
Asian tiger mosquito (Aedes albopictus) & $21.8[101]$ \\
Muskrat (Ondatra zibethicus) & $15.8[101]$ \\
Harlequin ladybird (Harmonia axyridis) & $10.9[119]$ \\
Grey squirrel (Sciurus carolinensis) & $9.2[119]$ \\
Asian hornet (Vespa velutina) & $7.9[101]$ \\
Raccoon dog (Nyctereutes procyonides) & $6.9[101]$ \\
American bullfrog (Lithobates catesbeiana) & $4.2[119]$ \\
Chinese mitten crab (Eriocheir sinensis) & $4.0[101]$ \\
Egyptian goose (Alopochen aegyptiacus) & $2.0[101]$ \\
Rose-ringed parakeet (Psittacula krameri) & $1.7[119]$ \\
Stone moroko (Pseudorasbora parva) & $1.0[101]$ \\
Varroa mite (Varroa destructor) & $0.8[119]$ \\
\hline
\end{tabular}

and Asian tiger mosquito (Aedes albopictus) were most often and stone moroko (Pseudorasbora parva) and varroa mite (Varroa destructor) least often correctly identified (Table 2). Men and biology students identified, on average, more IAAS correctly than did women and nonbiology students (gender: 1.3 and 0.8, respectively; subject: 1.0 and 0.8 , respectively).

In the model $\left(r^{2}=0.33\right)$, teacher students' "taxonomic knowledge" (square-root transformed) was related to gender and study subject (gender: $b=0.19, t=2.36, P=$ 0.019; study subject: $b=0.15, t=2.25, P=0.026)$. Moreover, there were differences between the two questionnaire versions $(b=0.62, t=9.74, P<0.001)$.

\section{General Opinion on the Management of IAAS (Objective 3)}

After teacher students had received some general information about invasive animal species (see 
Table 3. Teacher students' opinion on three types of management measures for 13 IAAS. Half of the students were briefly informed about the invasive status of the species depicted, while the other half were not

\begin{tabular}{|c|c|c|c|c|c|c|c|}
\hline \multirow{3}{*}{ IAAS } & \multicolumn{6}{|c|}{ Proportion of choices (\%) } & \multirow{3}{*}{$\begin{array}{l}\text { Chi-square value } \\
\text { and significance }\end{array}$} \\
\hline & \multicolumn{3}{|c|}{ With information } & \multicolumn{3}{|c|}{ Without information } & \\
\hline & eradication & $\begin{array}{l}\text { partial } \\
\text { removal }\end{array}$ & surveillance & eradication & $\begin{array}{l}\text { partial } \\
\text { removal }\end{array}$ & surveillance & \\
\hline Aedes albopictus & 84.3 & 13.7 & 2.0 & 64.7 & 25.5 & 9.8 & $5.78^{*}$ \\
\hline Varroa destructor & 82.8 & 15.5 & 1.7 & 63.5 & 26.9 & 9.6 & $6.22 *$ \\
\hline Vespa velutina & 54.9 & 35.3 & 9.8 & 25.0 & 45.8 & 29.2 & $10.98^{* *}$ \\
\hline Harmonia axyridis & 29.3 & 62.1 & 8.6 & 10.3 & 37.9 & 51.7 & $26.50 * * *$ \\
\hline Lithobates catesbeiana & 24.6 & 64.9 & 10.5 & 8.9 & 48.2 & 42.9 & $16.62^{* * *}$ \\
\hline Eriocheir sinensis & 22.4 & 59.2 & 18.4 & 6.4 & 68.1 & 25.5 & 5.11 \\
\hline Sciurus carolinensis & 19.6 & 73.2 & 7.1 & 1.7 & 31.0 & 67.2 & $45.77^{* * *}$ \\
\hline Nyctereutes procyonides & 15.7 & 70.6 & 13.7 & 6.5 & 71.7 & 21.7 & 2.68 \\
\hline Pseudorasbora parva & 15.7 & 70.6 & 13.7 & 2.1 & 31.3 & 66.7 & $30.05^{* * *}$ \\
\hline Alopochen aegyptiacus & 13.7 & 68.6 & 17.6 & 2.1 & 23.4 & 74.5 & $32.28 * * *$ \\
\hline Ondatra zibethicus & 5.9 & 72.5 & 21.6 & 4.1 & 57.1 & 38.8 & 3.54 \\
\hline Psittacula krameri & 3.4 & 50.0 & 46.6 & 0.0 & 20.3 & 79.7 & $14.45^{* *}$ \\
\hline Procyon lotor & 0.0 & 67.2 & 32.8 & 1.7 & 50.8 & 47.5 & 3.89 \\
\hline
\end{tabular}

${ }^{*}: P<0.05 ;{ }^{* *}: P<=0.01 ;{ }^{* * *}: P<0.001$

questionnaire 2, item 3 in Appendix A), they were asked whether they had already heard about IAAS. About $87 \%$ of the biology students but only $77 \%$ of the non-biology students answered the question with 'yes' $\left(\mathrm{chi}^{2}=51.14\right.$, $P<0.001)$.

In view of the participants, for IAAS that cause serious costs and problems, removal was clearly the best management option (Figure 1). Results of the ordinal regression analysis showed that teacher students' study subject (biology or not) was related to the decision for a certain type of management. Biology students were more likely to opt for one of the stricter types of management (partial or total removal of IAAS) than nonbiology students $(d f=1$, Wald $=4.74, P=0.030)$.

\section{Specific Opinion on the Management of the 13 IAAS Presented, either with or without prior Information about their Impact (Objective 4)}

Strong differences occurred between teacher students who had received information about the invasive character of the species presented and those who had not in their opinion on certain management measures (see questionnaire 2, version 1 and 2 in Appendix A). With prior information, students were more in favor of eradication and partial removal of IAAS than of surveillance (Table 3). However, the chosen management measure still depended on the species involved. Even with prior information, teacher students were less willing to remove mammals and birds than, for instance, insects and the varroa mite.

\section{DISCUSSION}

About half of the IAAS presented were perceived as beautiful. With exception of the harlequin ladybird (Harmonia axyridis), they were all vertebrates. Grey squirrel (Sciurus carolinensis), raccoon (Procyon lotor), raccoon dog (Nyctereutes procyonides) and rose-ringed parakeet (Psittacula krameri) were considered most beautiful, which is hardly surprising as humans tend to favor animals that are rather similar to them in appearance and behavior (Kellert, 1996; Stokes, 2007). Humans like furry creatures with large round eyes, i.e., grey squirrel, raccoon, and raccoon dog, the ability to sit upright and to skillfully handle objects with body parts, i.e., rose-ringed parakeet, and to interact socially with humans, i.e., grey squirrel, raccoon and rose-ringed parakeet (Lindemann-Matthies, 2005; Morris \& Morris, 1966; Prokop \& Fančovičová, 2013; Prokop \& Randler, 2018; Prokop \& Tunnicliffe, 2010; Stokes, 2007). In contrast, humans tend to avoid spiders and other invertebrates as they provoke fear and disgust (Morris \& Morris, 1965; Prokop \& Randler, 2018; Prokop \& Tunnicliffe, 2008; Shepard, 1997; Wagler \& Wagler, 2011). Amphibians were also found to cause disgust in humans (Prokop \& Fančovičová, 2012; Prokop, MedinaJerez, Coleman, Fančovičová, Özel, \& Fedor, 2016; Tomažič, 2011), which might explain the rather low aesthetic rating of the American bullfrog.

Perceived beauty and desirability (high scores on the "beautiful" and "wanted" side of the rating scales) were positively correlated. It should be noted that teacher students' characterizations were unaffected by information about the invasive status of the species presented as this information was provided only in the second questionnaire. As most participants did not recognize the species anyway, the results reflect unbiased feelings and preferences. Encounters with IAAS of a higher taxonomic order might thus evoke pleasurable (aesthetic) feelings, at least in laypersons without knowledge about IAAS, and a desire to keep them where they are.

With exception of the rose-ringed parakeet (Psittacula krameri) and the Chinese mitten crab (Eriocheir sinensis), 
all species were perceived as rather ordinary. Moreover, only P. krameri and the varroa mite (Varroa destructor) were perceived as exotic and (rather) unfamiliar. Grey squirrel (Sciurus carolinensis) and Asian ladybird (Harmonia axyridis), in particular, were perceived as native and familiar, which could be explained by a strong resemblance to their native counterparts, i.e., red squirrel (Sciurus vulgaris) and seven-spot ladybird (Coccinella septempunctata). As humans tend to forget quickly the nature of the past (shifting baseline syndrome; Kueffer \& Kull, 2017), participants of the present study might have perceived raccoon (Procyon lotor) and muskrat (Ondatra zibethicus) as native parts of the German landscape, despite the fact that they were both introduced. Feelings of familiarity and nativeness, which were positively correlated, and a lack of "taxonomic" knowledge might thus severely bias laypersons' perception of IAAS. Perceived familiarity with an IAS, in particular, has been found to have a mitigating effect on risk perception, and perceptions of risk increases if a species is perceived to be non-native (Humair, Kueffer, \& Siegrist, 2014).

Biology students identified more IAAS correctly than did students of other subjects, and were more likely to opt for a stricter management of IAAS. This is a first indication that the acceptance of a control management of IAAS can be positively related to biological/environmental background knowledge (see also Fischer \& van der Wal, 2006; García-Llorente et al., 2008). However, systematic biology has been drastically reduced in recent decades at European universities, leading to academics, teachers included, who can barely identify organisms (Bilton, 2014; Leather \& Quicke, 2009; 2010). Moreover, as knowledge of species is no longer needed in industrialized high-income countries to sustain people's livelihoods (Pilgrim, Cullen, Smith, \& Pretty, 2008), laypersons' ability to identify species is very poor (e.g., Hooykaas, Schilthuizen, Aten, Hemelaar, Albers, \& Smeets, 2019; Palmberg et al., 2015; Randler, 2008).

After half of our participants had been informed about the negative impact of the IAAS presented, they were indeed more supportive of a total or partial removal of IAAS than participants without such information. Informed teacher students agreed most with a partial removal of IAAS and, in case of invertebrates such as Asian hornet (Vespa velutina), Asian tiger mosquito (Aedes albopictus) and varroa mite (Varroa destructor) with total eradication. Even in case of the highly attractive grey squirrel (Sciurus carolinensis), no control was hardly an option for the informed group of participants. This result is in contrast to a study on invasive alien plant species (IAPS), where the willingness to remove an IAPS and to report it to the authorities decreased with increasing beauty of a species (Lindemann-Matthies, 2016). Even when laypersons had been informed about IAPS and the problems they can cause, they still felt that the beauty of some IAPS in settlement areas may outweigh the damage they can cause. Likewise, laypersons in South Africa and in the UK were still against the control of the invasive grey squirrel ( $S$. carolinensis), which they considered beautiful, after receiving information about its negative impact (Novoa et al., 2017).

There are certain limitations to the present study. Participants were a convenience sample, and results cannot be generalized to teacher students in Germany. Moreover, to reduce the number of species a participant had to identify, two questionnaire versions were provided. The number of IAAS that a teacher student correctly identified varied significantly between the two versions. We can only assume that the species shown in one version were easier to identify than the species shown in the other version. In addition, although the results provide evidence for a short-term effect of information on teacher students' attitudes, it is not clear whether this will be the case in the long term. Furthermore, our questions related to certain management types were just hypothetical, and the answers might not hold in reality. Invasive species management often includes population reduction through lethal control, which is controversially discussed (as outlined in Crowley et al., 2019). It therefore raises the question of how teacher students would actually react if cute raccoons or attractive roseringed parakeets were deliberately killed near their homes.

\section{CONCLUSIONS}

The present results highlight the importance of information on IAAS so that laypersons can understand the reasons for certain types of management. Even a short description of the invasive nature of a species was rather effective in this regard. Impact information may lead to more informed and differentiated attitudes in the invasive species debate, although in case of some "loveable" species such as raccoon (Procyon lotor) and rose-ringed parakeet (Psittacula krameri), even this might not always work. Nevertheless, mere information is not enough. If laypersons cannot identify local wild plant and animal species in their surroundings, they will certainly not recognize IAS and, as the present results exemplify, might even perceive them as native. As "native" is the accepted group of species in the invasive species debate, and, in the present study, "native" also means "wanted", a lack of "taxonomic" knowledge might seriously bias laypersons attitudes towards IAS. It would thus be an important task for preservice teachereducation to familiarize students of biology with both native and introduced species, and with suitable approaches on how to deal with the topics of biological invasions in school. Curricular changes in biology teacher education, i.e., a stronger focus on taxonomy and invasive species, might be a first step. If teacher students 
are better able to identify IAAS, they might also be more able to teach the subject of IAAS in school.

To conclude, it is not enough to deliver information on invasive alien animal species to wildlife managers and other stakeholders involved in the management of IAAS. Information should also be delivered to students in school as they are the decision-makers of tomorrow. It is thus worthwhile to focus on teacher students' education as they will be important multipliers of knowledge on biological invasions in the future.

\section{ACKNOWLEDGEMENTS}

We would like to thank Lena Feil and Daniela Röder for their help in acquiring the data.

\section{REFERENCES}

Albert, C., Luque, G. M., \& Courchamp, F. (2018). The twenty most charismatic species. PloS one, 13(7), e0199149. https://doi.org/10.1371/journal.pone. 0199149

Bardsley, D. K., \& Edwards-Jones, G. (2007). Invasive species policy and climate change: social perceptions of environmental change in the Mediterranean. Environmental Science and Policy, 10, 230-242. https://doi.org/10.1016/j.envsci.2006.12. 002

Bartoszewicz, M. (2011). NOBANIS - Invasive alien species fact sheet - Procyon lotor. Online database of the European Network on Invasive Alien Species (NOBANIS). Retrieved from https://www. nobanis.org/globalassets/speciesinfo/p/procyo n-lotor/procyon_lotor.pdf

Bellard, C., Leroy, B., Thuiller, W., Rysman, J. F., \& Courchamp, F. (2016). Major drivers of invasion risks throughout the world. Ecosphere, 7, e01241. https:/ / doi.org/10.1002/ecs2.1241

Benedict, M. Q., Levine, R. S., Hawley, W. A., \& Lounibos, L. P. (2007). Spread of the tiger: global risk of invasion by the mosquito Aedes albopictus. Vector-borne and Zoonotic Diseases, 7, 76-85. https:// doi.org/10.1089/vbz.2006.0562

Bertolino, S., \& Genovesi, P. (2003). Spread and attempted eradication of the grey squirrel (Sciurus carolinensis) in Italy, and consequences for the red squirrel (Sciurus vulgaris) in Eurasia. Biological Conservation, 109, 351-358. https:/ / doi.org/10.1016/S0006-3207(02)00161-1

Beyer, K., Copp, G. H., \& Gozlan, R. E. (2007). Microhabitat use and interspecific associations of introduced topmouth gudgeon Pseudorasbora parva and native fishes in a small stream. Journal of Fish Biology, 71, 224-238. https:/ / doi.org/10.1111/j.1095-8649.2007.01677.x
Bilton, D. T. (2014). What's in a name? What have taxonomy and systematics ever done for us? Journal of Biological Education, 48, 116-118. https:/ / doi.org/10.1080/00219266.2014.926653

Birnbaum, C. (2011). NOBANIS - Invasive alien species fact sheet - Ondatra zibethicus. Online database of the European Network on Invasive Alien Species (NOBANIS). Retrieved from https://www. nobanis.org/globalassets/speciesinfo/o/ondatra -zibethicus/ondatra_zibethicus.pdf

Bourassa, S. C. (1991). The aesthetics of landscape. London, UK: Belhaven Press.

Bremner, A., \& Park, K. (2007). Public attitudes to the management of invasive non-native species in Scotland. Biological Conservation, 139, 306-314. https:/ / doi.org/10.1016/j.biocon.2007.07.005

CBD (Convention on Biological Diversity) (2009). What are invasive alien species? Retrieved from https://www.cbd.int/idb/2009/about/what/

Clergeau, P., \& Vergnes, A. (2011). Bird feeders may sustain feral Rose-ringed parakeets Psittacula krameri in temperate Europe. Wildlife Biology, 17, 248-253. https:/ / doi.org/10.2981/09-092

Colléony, A., Clayton, S., Couvet, D., Saint Jalme, M., \& Prévot, A. C. (2017). Human preferences for species conservation: animal charisma trumps endangered status. Biological Conservation, 206, 263-269. https:// doi.org/10.1016/j.biocon.2016.11.035

Crawley, M. J. (2005). Statistics: an introduction using $R$. Chichester, UK: Wiley.

Crowley, S. L., Hinchliffe, S., \& McDonald, R. A. (2019). The parakeet protectors: understanding opposition to introduced species management. Journal of Environmental Management, 229, 120-132. https:/ / doi.org/10.1016/j.jenvman.2017.11.036

Dittel, A. I., \& Epifanio, C. E. (2009). Invasion biology of the Chinese mitten crab Eriocheir sinensis: a brief review. Journal of Experimental Marine Biology and Ecology, 374(2), 79-92.

Dunn, M., Marzano, M., Forster, J., \& Gill, R. M. (2018). Public attitudes towards "pest" management: perceptions on squirrel management strategies in the UK. Biological Conservation, 222, 52-63. https:/ / doi.org/10.1016/j.biocon.2018.03.020

Duscher, T., Hodžić, A., Glawischnig, W., \& Duscher, G. G. (2017). The raccoon dog (Nyctereutes procyonoides) and the raccoon (Procyon lotor) their role and impact of maintaining and transmitting zoonotic diseases in Austria, Central Europe. Parasitology Research, 116, 1411-1416. https:/ / doi.org/10.1007/s00436-017-5405-2

Early, R., Bradley, B. A., Dukes, J. S., Lawler, J. J., Olden, J. D., Blumenthal, D. M., ... Sorte, C. J. (2016). Global threats from invasive alien species in the twenty- 
first century and national response capacities. Nature Communications, 7, 12485. https:/ / doi.org/10.1038/ncomms12485

Estévez, R. A., Anderson, C. B., Pizarro, J. C., \& Burgman, M. A. (2015). Clarifying values, risk perceptions, and attitudes to resolve or avoid social conflicts in invasive species management. Conservation Biology, 29, 19-30. https:/ / doi.org/10.1111/cobi.12359

European Commission (2017). Invasive alien species of Union concern. Luxembourg: Publications Office of the European Union.

European Commission (2017). Invasive alien species of Union concern. Luxembourg: Publications Office of the European Union.

European Union (2014). Regulation (EU) No 1143/2014 of the European Parliament and of the Council of 22 October 2014 on the prevention and management of the introduction and spread of invasive alien species. Retrieved from http://data.europa.eu/eli/reg/ 2014/1143/oj

Fischer, A., \& van der Wal, R. (2006). Invasive plant suppresses charismatic seabird - the construction of attitudes towards biodiversity management options. Biological Conservation, 135, 256-267. https://doi.org/10.1016/j.biocon.2006.10.026

Fischer, M. L., Hochkirch, A., Heddergott, M., Schulze, C., Anheyer-Behmenburg, H. E., Lang, J., ... Klein, R. (2015). Historical invasion records can be misleading: genetic evidence for multiple introductions of invasive raccoons (Procyon lotor) in Germany. Plos one, 10, e0125441. https://doi.org/10.1371/journal.pone.0125441

Forshaw, J. M. (2010). Parrots of the World (Vol. 70). Princeton, NJ: Princeton University Press.

García-Llorente, M., Martín-López, B., González, J. A., Alcorlo, P., \& Montes, C. (2008). Social perceptions of the impacts and benefits of invasive alien species: implications for management. Biological Conservation, 141, 2969-2983. https://doi.org/10. 1016/j.biocon.2008.09.003

Garner, T. W., Perkins, M. W., Govindarajulu, P., Seglie, D., Walker, S., Cunningham, A. A., \& Fisher, M. C. (2006). The emerging amphibian pathogen Batrachochytrium dendrobatidis globally infects introduced populations of the North American bullfrog, Rana catesbeiana. Biology Letters, 2, 455459. https:/ / doi.org/10.1098/rsbl.2006.0494

Gollasch, S. (2011): NOBANIS - Invasive alien species fact sheet - Eriocheir sinensis. Online Database of the European Network on Invasive Alien Species (NOBANIS). Retrieved from https://www. nobanis.org/globalassets/speciesinfo/e/eriochei r-sinensis/eriocheir_sinensis.pdf
Gratz, N. G. (2004). Critical review of the vector status of Aedes albopictus. Medical and Veterinary Entomology, 18, 215-227. https://doi.org/10.1111/ j.0269-283X.2004.00513.x

Gurnell, J., Rushton, S. P., Lurz, P. W. W., Sainsbury, A. W., Nettleton, P., Shirley, M. D. F., ... Geddes, N. (2006). Squirrel poxvirus: landscape scale strategies for managing disease threat. Biological Conservation, 131, 287-295. https://doi.org/ 10.1016/j.biocon.2006.04.009

Heink, U., \& Jax, K. (2014). Framing biodiversity - the case of "invasive alien species". In D. Lanzerath, \& M. Friele (Eds.), Concepts and values in biodiversity (pp. 73-98). London, UK: Routledge.

Helle, E., \& Kauhala, K. (1991). Distribution history and present status of the raccoon dog in Finland. Ecography, 14, 278-286. https://doi.org/10.1111/ j.1600-0587.1991.tb00662.x

Hooykaas, M. J., Schilthuizen, M., Aten, C., Hemelaar, E. M., Albers, C. J., \& Smeets, I. (2019). Identification skills in biodiversity professionals and laypeople: a gap in species literacy. Biological Conservation, 238. https://doi.org/10.1016/j.biocon.2019.108202

Hulme, P. E., Brundu, G., Carboni, M., Dehnen-Schmutz, K., Dullinger, S., Early, R., ... Kühn, I. (2018). Integrating invasive species policies across ornamental horticulture supply chains to prevent plant invasions. Journal of Applied Ecology, 55, 92-98. https:/ / doi.org/10.1111/1365-2664.12953

Hulme, P. E., Pyšek, P., Jarošík, V., Pergl, J., Schaffner, U., \& Vilà, M. (2013). Bias and error in understanding plant invasion impacts. Trends in Ecology and Evolution, 28, 212-218. https:/ / doi.org/10.1016/j.tree.2012.10.010

Humair, F., Humair, L., Kuhn, F., \& Kueffer, C. (2015). Ecommerce trade in invasive plants. Conservation Biology, 29, 1658-1665. https://doi.org/10.1111/ cobi.12579

Humair, F., Kueffer, C., \& Siegrist, M. (2014). Are nonnative plants perceived to be more risky? Factors influencing horticulturists' risk perception of ornamental plant species. Plos One, 9(7), e102121. https:// doi.org/10.1371/journal.pone.0102121

Keller, R. P., \& Perrings, C. (2011). International policy options for reducing the environmental impacts of invasive species. BioScience, 61, 1005-1012. https:/ / doi.org/10.1525/bio.2011.61.12.10

Keller, R. P., Geist, J., Jeschke, J. M., \& Kühn, I. (2011). Invasive species in Europe: ecology, status, and policy. Environmental Sciences Europe, 23, 1-17. https:// doi.org/10.1186/2190-4715-23-23

Kellert, S. R. (1996). The value of life: biological diversity and human society. Washington, DC: Island Press.

Kueffer, C., \& Kull, C. A. (2017). Non-native species and the aesthetics of nature. In M. Vilà, \& P. Hulme 
(Eds.), Impact of biological invasions on ecosystem services (pp. 311-324). Cham, Switzerland: Springer.

Leather, S. R., \& Quicke, D. J. (2009). Where would Darwin have been without taxonomy? Journal of Biological Education, 43, 51-52. https://doi.org/ 10.1080/00219266.2009.9656151

Leather, S. R., \& Quicke, D. J. (2010). Do shifting baselines in natural history knowledge threaten the environment? The Environmentalist, 30, 1-2. https:// doi.org/10.1007/s10669-009-9246-0

Lindemann-Matthies, P. (2005). Lovable mammals and lifeless plants: how children's interest in common local organisms can be enhanced through observation of nature. International Journal of Science Education, 27, 655-677. https://doi.org/10.1080/ 09500690500038116

Lindemann-Matthies, P. (2016). Beasts or beauties? Laypersons' perception of invasive alien plant species in Switzerland and attitudes towards their management. NeoBiota, 29, 15-33. https:// doi.org/10.3897/neobiota.29.5786

Lorimer, J. (2007). Nonhuman charisma. Environment and Planning D: Society and Space, 25, 911-932. https://doi.org/10.1068/d71j

Lundberg, A. (2010). Conflicts between perception and reality in the management of alien species in forest ecosystems: a Norwegian case study. Landscape Research, 35, 319-338. https://doi.org/10.1080/ 01426391003746523

Lute, M. L., \& Attari, S. Z. (2017). Public preferences for species conservation: choosing between lethal control, habitat protection and no action. Environmental Conservation, 44, 139-147. https:/ / doi.org/10.1017/S037689291600045X

Majerus, M., Strawson, V., \& Roy, H. (2006). The potential impacts of the arrival of the harlequin ladybird, Harmonia axyridis (Pallas) (Coleoptera: Coccinellidae), in Britain. Ecological Entomology, 31, 207-215. https://doi.org/10.1111/j.13652311.2006.00734.x

MEA (Millennium Ecosystem Assessment) (2005). Ecosystems and human well-being. London, UK: Island Press.

Minteer, B. A., \& Collins, J. P. (2005). Why we need an "ecological ethics". Frontiers in Ecology and the Environment, 3, 332-337. https://doi.org/10.1890/ 1540-9295(2005)003[0332:WWNAEE]2.0.CO,2

Monceau, K., Bonnard, O., \& Thiéry, D. (2014). Vespa velutina: a new invasive predator of honeybees in Europe. Journal of Pest Science, 87, 1-16. https:// doi.org/10.1007/s10340-013-0537-3

Morris, D., \& Morris, R. (1965). Men and snakes. London, UK: Hutchinson \& Co.
Morris, D., \& Morris, R. (1966). Men and pandas. London, UK: Sphere Books Limited.

Myers, J. H., \& Cory, J. S. (2017). Biological control agents: invasive species or valuable solutions? In M. Vilà, \& P. E. Hulme (Eds.), Impact of biological invasions on ecosystem services (pp. 191-202). Springer, Cham.

Novoa, A., Dehnen-Schmutz, K., Fried, J., \& Vimercati, G. (2017). Does public awareness increase support for invasive species management? Promising evidence across taxa and landscape types. Biological Invasions, 19, 3691-3705. https://doi.org/10.1007/ s10530-017-1592-0

Orchard, S. A. (2011). Removal of the American bullfrog, Rana (Lithobates) catesbeiana, from a pond and a lake on Vancouver Island, British Columbia, Canada. In C. R. Veitch, M. N. Clout, \& D. R. Towns: Island invasives: eradication and management (pp. 217-221). Gland, Switzerland: IUCN.

Palmberg, I., Berg, I., Jeronen, E., Kärkkäinen, S., Norrgård-Sillanpää, P., Persson, C., ... Yli-Panula, E. (2015). Nordic-Baltic student teachers' identification of and interest in plant and animal species: the importance of species identification and biodiversity for sustainable development. Journal of Science Teacher Education, 26, 549-571. https:// doi.org/10.1007/s10972-015-9438-z

Pârâu, L. G., Strubbe, D., Mori, E., Menchetti, M., Ancillotto, L., Kleunen, A. V., ... Clergeau, P. (2016). Rose-ringed parakeet Psittacula krameri populations and numbers in Europe: a complete overview. The Open Ornithology Journal, 9, 1-13. https:// doi.org/10.2174/1874453201609010001

Pilgrim, S. E., Cullen, L. C., Smith, D. J., \& Pretty, J. (2008). Ecological knowledge is lost in wealthier communities and countries. Environmental Science $\mathcal{E}$ Technology, 42, 1004-1009. https://doi.org/ $10.1021 / \mathrm{es} 070837 \mathrm{v}$

Pinder, A. C., Gozlan, R. E., \& Britton, J. R. (2005). Dispersal of the invasive topmouth gudgeon, Pseudorasbora parva in the UK: a vector for an emergent infectious disease. Fisheries Management and Ecology, 12, 411-414. https:/ / doi.org/10.1111/j.1365-2400.2005.00466.x

Prokop, P., \& Fančovičová, J. (2012). Tolerance of amphibians in Slovakian people: a comparison of pond owners and non-owners. Anthrozoös, 25, 277288. https:// doi.org/10.2752/175303712X13403555 186136

Prokop, P., \& Fančovičová, J. (2013). Does colour matter? The influence of animal warning coloration on human emotions and willingness to protect them. Animal Conservation, 16, 458-466. https://doi.org/10.1111/acv.12014 
Prokop, P., \& Randler, C. (2018). Biological predispositions and individual differences in human attitudes toward animals. In R. R. N. Alves, \& A. P. D. de Albuquerque (Eds.), Ethnozoology: animals in or lives (pp. 447-466). London, UK: Academic Press.

Prokop, P., \& Tunnicliffe, S. D. (2008). "Disgusting" animals: primary school children's attitudes and myths of bats and spiders. Eurasia Journal of Mathematics, Science E Technology Education, 4, 8797. https://doi.org/10.12973/ejmste/75309

Prokop, P., \& Tunnicliffe, S. D. (2010). Effects of having pets at home on children's attitudes toward popular and unpopular animals. Anthrozoös, 23, 2135. https:/ / doi.org/10.2752/175303710X126270799 39107

Prokop, P., Medina-Jerez, W., Coleman, J., Fančovičová, J., Özel, M., \& Fedor, P. (2016). Tolerance of frogs among high school students: influences of disgust and culture. Eurasia Journal of Mathematics, Science $\mathcal{E}$ Technology Education, 12, 1499-1505. https://10.12973/eurasia.2016.1241a

Randler, C. (2008). Teaching species identification - a prerequisite for learning biodiversity and understanding ecology. Eurasia Journal of Mathematics, Science and Technology Education, 4, 223-231. https:/ / doi.org/10.12973/ejmste/75344

Rosenkranz, P., Aumeier, P., \& Ziegelmann, B. (2010). Biology and control of Varroa destructor. Journal of Invertebrate Pathology, 103, S96-S119. https:/ / doi.org/10.1016/j.jip.2009.07.016

Shackleton, R. T., Richardson, D. M., Shackleton, C. M., Bennett, B., Crowley, S. L., Dehnen-Schmutz, K., ... Marchante, E. (2019b). Explaining people's perceptions of invasive alien species: a conceptual framework. Journal of Environmental Management, 229, 10-26. https://doi.org/10.1016/j.jenvman. 2018.04.045

Shepard, P. (1997). The others. Washington, DC: Island Press.
Simberloff, D., Martin, J.-L., Genovesi, P., Maris, V., Wardle, D. A., Aronson, J., ... Vilà, M. (2013). Impacts of biological invasions: what's what and the way forward. Trends in Ecology and Evolution, 28, 58-66. https:/ / doi.org/10.1016/j.tree.2012.07.013

Smith, K. F., Behrens, M., Schloegel, L. M., Marano, N., Burgiel, S., \& Daszak, P. (2009). Reducing the risks of the wildlife trade. Science, 324, 594-595. https:// doi.org/10.1126/science.1174460

Stokes, D. L. (2007). Things we like: human preferences among similar organisms and implications for conservation. Human Ecology, 35, 361-369. https:/ / doi.org/10.1007/s10745-006-9056-7

Strubbe, D., \& Matthysen, E. (2007). Invasive ringnecked parakeets Psittacula krameri in Belgium: habitat selection and impact on native birds. Ecography, 30, 578-588. https://doi.org/10.1111/ j.0906-7590.2007.05096.x

Strubbe, D., \& Matthysen, E. (2009). Experimental evidence for nest-site competition between invasive ring-necked parakeets (Psittacula krameri) and native nuthatches (Sitta europaea). Biological Conservation, 142, 1588-1594. https:/ / doi.org/10.1016/j.biocon.2009.02.026

Vilà, M., Espinar, J. L., Hejda, M., Hulme, P. E., Jarošík, V., Maron, J. L., ... Pyšek, P. (2011). Ecological impacts of invasive alien plants: a meta-analysis of their effects on species, communities and ecosystems. Ecology Letters, 14, 702-708. https:/ / doi.org/10.1111/j.1461-0248.2011.01628.x

Wagler, R., \& Wagler, A. (2011). Arthropods: attitude and incorporation in preservice elementary teachers. International Journal of Environmental and Science Education, 6(3), 229-250.

Waliczek, T. M., Williamson, P. S., \& Oxley, F. M. (2017). College student knowledge and perceptions of invasive species. HortTechnology, 27, 550-556. https:/ / doi.org/10.21273/HORTTECH03709-17 


\section{APPENDIX A}

\section{Questionnaire 1}

(1) Characterize the following animal species with the help of the five opposing attributes (ugly-beautiful; extraordinary-ordinary; exotic-indigenous; unfamiliar-familiar; unwanted-wanted). Be careful not to leave one out.

(2) Do you know the names of the animals depicted (no, yes)? If yes, write them down

\section{Questionnaire 2}

\section{Version 1}

(3) Please read the following text carefully: "All animals shown as photographs do not occur naturally in Germany. They were brought here by humans and are called alien or non-indigenous species. Most non-indigenous species do not cause problems. However, some can begin to spread rapidly, causing unwanted impacts on other animals, health problems and/or economic costs. These animals are called "invasive animals". Have you heard about invasive animals (yes, no)?

(4) Should something be done against invasive animals? Tick the one statement you agree most with: no intervention; no removal of aesthetically pleasing animals, but removal of less appealing ones; removal of only those invasive animals that provoke serious problems and costs; removal of all invasive animals in order to conserve unique habitats and species.

(5) What should be done with these species? (shown as pictures without further information) Tick the one management option you most agree with: no intervention; partial control of populations; eradication

(6) Personal data: sex, age, place of living (large city with more than 100,000 inhabitants; medium-sized city with 50,000-100,000 inhabitants; small city with less than 50,000 inhabitants; rural area), biology as a study subject (yes, no)

\section{Version 2}

(3) Please read the following text carefully: "All animals shown as photographs do not occur naturally in Germany. They were brought here by humans and are called alien or non-indigenous species. Most non-indigenous species do not cause problems. However, some can begin to spread rapidly, causing unwanted impacts on other animals, health problems and/or economic costs. These animals are called "invasive animals". Have you heard about invasive animals (yes, no)?

(4) Should something be done against invasive animals? Tick the one statement you agree most with: no intervention; no removal of aesthetically pleasing animals, but removal of less appealing ones; removal of only those invasive animals that provoke serious problems and costs; removal of all invasive animals in order to conserve unique habitats and species.

(5) Read the short info text and mark with a cross how you think the animal should be handled (information on each species in Appendix B). Tick the one management option you most agree with: no intervention; partial control of populations; eradication

(6) Personal data: sex, age, place of living (large city with more than 100,000 inhabitants; medium-sized city with 50,000-100,000 inhabitants; small city with less than 50,000 inhabitants; rural area), biology as a study subject (yes, no) 


\section{APPENDIX B}

\section{Information on IAAS (See Questionnaire 2, Version 2, Item 5 in Appendix A)}

(1) Raccoons are native to North America and, at the moment, widespread in Germany. They eat the eggs and young of ground- and tree-nesting birds. However, studies so far have not reported serious damage caused by raccoons on other species. Many raccoons live in cities, where they find food in abundance. They plunder fruit trees, raid garbage cans and devastate gardens. When raccoons take up residence inside an attic they can cause tremendous amounts of property damage.

(2) Muskrats are native to North America. They live in slow-moving or stagnant water. Due to their burrowing activities they can damage dams, dykes and embankments. As herbivores they contribute in many areas to the destruction of water plants and reed belt communities.

(3) Raccoon dogs are native to East Asia. They have no natural enemies in Europe, and their numbers are steadily increasing. Raccoon dogs are omnivores, inhabit areas in forests with numerous water sources, and find shelter in abandoned fox burrows. They are suspected of endangering indigenous species, and are an important vector of zoonoses and parasites.

(4) Grey squirrels plunder the nests of songbirds and gnaw off the bark of beech and oak trees; many of these trees even die. Furthermore, they out-compete the native red squirrel as they are more robust and twice as heavy. Grey squirrels transmit a smallpox disease which does not appear to affect their own health but often kills red squirrels.

(5) Originally from Africa and Asia, the rose-ringed parakeet is now found in many German cities. Rose-ringed parakeets use large trees with natural cavities for nesting, and occasionally damage house walls by biting breeding holes into insulation layers. Their loud screeching calls can be hard to bear for local residents.

(6) Native to Africa, the Egyptian goose has been introduced to Europe, where it inhabits almost every type of water body. During breeding season, Egyptian geese display a pronounced aggressive behaviour towards other water birds. The species appears to be expanding rapidly, with potential deleterious effects on other wildfowl.

(7) The North American bullfrog can grow up to $60 \mathrm{~cm}$ and make sounds that are similar to an ox roar. Bullfrogs eat all animals that are smaller than themselves, i.e., insects, fish, mice and also amphibians. They are thus a thread to many native amphibian species.

(8) Stone morokos are native to East Asia. They have strongly increased in Europe due to a rapid reproduction rate and high dispersal potential. As competitors for food and habitats, they can threaten native fish species with similar demands and contribute to the impoverishment of water bodies.

(9) Harlequin ladybirds eat five times more aphids than native ones. For this reason they were imported to Germany. When they started to spread uncontrollably, trade was stopped - but too late. Harlequin ladybirds gather in large numbers in the fall, looking for a place to spend the winter. Attracted to homes and buildings with sunny exposures, they will cluster on outside walls and eventually work their way indoors through cracks and openings. Asian ladybirds do not only eat aphids but also useful insects and native ladybirds. They also spread faster than the local ones. Due to their foul tasting and smelling body fluid they have hardly any natural enemies.

(10) The Asian hornet is native to East Asia. Within a short time, it can reach considerable population densities in its populated regions. Asian hornets do not behave aggressively towards humans. As bee hunters, however, they can severely threaten honey production, which is why beekeepers fight the hornet.

(11) The Asian tiger mosquito is one of the most aggressively spreading species in the world. The species originates from East Asia but in the meantime has invaded almost all parts of the world. Through bites, Asian tiger mosquitoes transmit pathogens of Chikungunya, dengue, yellow fever and West Nile viruses.

(12) The varroa mite is an external parasite that attacks all lifecycle stages of honeybees. Varroa mites reproduce and develop in the capped brood within a bee hive. They weaken the brood and transmit diseases. Untreated infestations will destroy entire honeybee colonies. In Austria, the species has to be announced to the authorities.

(13) The Chinese mitten crab has its origin in China and mainly populates larger river courses. Water plants, insect larvae, mussels and smaller fish serve as food for the nocturnal crab. It is in direct competition with native crayfish species. Occasionally, bank structures and dams are damaged by the massive digging of hollow passages. Fishing nets and fishing lines are also cut by the Chinese crab, which then eats the bait and caught fish. 


\section{APPENDIX C}

\section{Background Information on the 13 IAAS}

(1) The raccoon (Procyon lotor) is native to Central and North America. The species is abundant and widespread in Germany, where it was first introduced in the 1930s (Fischer et al., 2015). P. lotor can have economic impacts on agricultural production through crop and fowl depredation as well as health and economic implications through its role as host to various zoonoses, some of which are lethal to humans (Bartoszewicz, 2011). A sales ban, the phasing out from zoos, collections or any other ownership, a rapid eradication of any newly emerging populations, and the management of established populations should prevent the species from further spread (European Commission, 2017).

(2) The muskrat (Ondatra zibethicus) is native to North America and has been introduced for its fur to much of Europe (Birnbaum, 2013). It inhabits wetlands and feeds mainly on the plants of reed belt communities. There, it damages vegetation, banks and other structures by burrowing. Moreover, O. zibethicus can threaten populations of a variety of native species (European Commission, 2017). Union level action includes a ban on keeping and selling, a rapid eradication of newly establishing populations and containment of the invasion, especially keeping them out of protected areas (European Commission, 2017). However, especially in Northern Europe the general opinion on the impact of $O$. zibethicus is equivocal as the species can also prevent lakes from being overgrown by vegetation (Birnbaum, 2013).

(3) The raccoon dog (Nyctereutes procyonides) is native to East Asia and considered invasive in its introduced range in Europe. It has spread rapidly into many European countries after being introduced by Russians during the first half of the 20th century (Helle \& Kauhala, 1991). N. procyonides is a predator of native birds and frogs, but firm evidence of this is lacking. It is also an important vector of rabies and some parasites, such as Echinococcus multilocularis (Duscher, Hodžić, Glawischnig, \& Duscher, 2017). Union level action includes a ban on keeping and selling the species, a rapid eradication obligation of newly emerging populations and the management of established populations in order to prevent the species from becoming a wider problem across the EU and to keep them out of protected areas (European Commission, 2017).

(4) The grey squirrel (Sciurus carolinensis) is native to deciduous forests in North America and has been introduced to the UK, Ireland, Italy and South Africa. In its introduced range, grey squirrels can damage trees by stripping the bark. In Europe they can cause the local extinction of the red squirrel (Sciurus vulgaris) through competition and disease. Grey squirrels act as a reservoir for a poxvirus which can be fatal to S. vulgaris (Gurnell et al., 2006). The import of this species has already been banned through the EU Wildlife Trade Regulation, but placing it on the Union list will further contain the invasion by prohibiting its sales, phasing out its keeping and requiring a rapid eradication of any newly observed population and management of the established populations (European Commission, 2017).

(5) The rose-ringed parakeet (Psittacula krameri) is native to Asia and Sub-Saharan Africa (Forshaw, 2010). It is found in a variety of forested and other habitats, including parks and gardens in urban areas. Due to its popularity as a cage bird, it has succeeded in establishing feral populations almost worldwide (Pârâu et al., 2016). In the $1960^{\text {th }}$, the species was introduced to Germany, and since then has established populations especially in the Rhine valley (Strubbe \& Matthysen, 2009). P. krameri is known to compete for nesting cavities with native hole-nesting birds (Strubbe \& Matthysen, 2007). Supplemental food found in suburban private gardens and public parks (nutritious and all year round) appears to be important for the persistence of this exotic bird species (Clergeau \& Vergnes, 2011).

(6) The Egyptian goose (Alopochen aegyptiacus) is native to Africa. It was first introduced to Europe as an ornamental specimen for zoological collections and urban parks, and has since escaped into the wild. It is now established in eight countries: the United Kingdom, the Netherlands, Belgium, Germany, Sweden, Cyprus, Denmark and Poland. The species appears to be expanding rapidly, with potential deleterious effects on other wildfowl (EU Commission, 2017). A sales ban, the phasing out from zoos, collections and any other ownership, a rapid eradication of any newly emerging populations and the management of established populations should prevent the species from becoming a wider problem across the EU (EU Commission, 2017).

(7) The American bullfrog (Lithobates catesbeiana) is native to North America and has been introduced worldwide for human consumption (Orchard, 2011). Larvae can have a significant impact upon benthic algae, and thus perturb aquatic community structure. Adults may be responsible for significant levels of predation on native anurans and other aquatic herpetofauna, such as snakes and turtles. The species also contributes to the spread of pathogens such as the chytrid fungus (Garner et al., 2006). The import of L. catesbeiana has already been banned through the EU Wildlife Trade Regulation, but its inclusion on the Union list of Invasive Alien Species 
will ensure further concerted action to contain its invasion and prevent its spread into other countries (European Commission, 2017).

(8) The stone moroko (Pseudorasbora parva) is native to East Asia. Introduced to Romania in the early 1960s as a contaminant of Chinese carp consignments, $P$. parva had invaded freshwaters of most every country in Europe (Beyer, Copp, \& Gozlan, 2007). Potential impacts by P. parva are numerous, as the species is a known facultative parasite and host of the rosette agent (Pinder, Gozlan, \& Britton, 2005). An EU-level ban on keeping, including in aquaria, or releasing the species, action on pathways of introduction and spread, and rapid eradication of any newly emerging population will prevent its further invasion. Where the species has become widely spread, appropriate management measures have to be taken (European Commission, 2017).

(9) The harlequin ladybird (Harmonia axyridis) is native to Asia, and has been used worldwide for biological control of various aphid species. There is convincing evidence that $H$. axyridis decreases the diversity of native ladybird species in Europe (Myers \& Cory, 2017). Moreover, H. axyridis inhabits wine grape orchards and, when harvested along with the grapes, causes an unpleasant odor and taste in the resultant wine. It can also be a nuisance to humans as, during the winter months, the species takes up residency in walls and insulation of houses and other structures in large numbers (Majerus, Strawson, \& Roy, 2006).

(10) The Asian hornet (Vespa velutina) is native to Asia and a predator of social hymenopterans, in particular of honey bees (Apis mellifera). The subspecies V. v. nigrithorax has been accidentally introduced to Europe where it was first recorded from southern France in 2004. Since then it has been found in Spain, Portugal, Belgium, Italy, UK, the Netherlands, and recently also in the region of Karlsruhe, Germany (European Commission, 2017). V. velutina threatens honey production and native pollinating insects. In the current pollinator decline, the species is an additional stressor for honeybees and other pollinators (Monceau, Bonnard, \& Thiéry, 2014). EU-level action seeks to prevent the spread of $V$. velutina by inter alia rapidly destroying its nests. In addition, where the species has become widely spread, appropriate management measures have to be taken (European Commission, 2017).

(11) The Asian tiger mosquito (Aedes albopictus) is native to South-east Asia, islands of the Western Pacific and the Indian Ocean, and has spread during recent decades to Africa, the Mid-East, Europe and America (Gratz, 2004). Invasions into new areas of its potential range are apparently due to transportation of dormant eggs in used tires (Benedict, Levine, Hawley, \& Lounibos, 2007). The tiger mosquito is associated with the transmission of many human diseases, including Dengue, West Nile and Japanese Encephalitis viruses (Gratz, 2004).

(12) The varroa mite (Varroa destructor) is native to Asia. It is an external parasite that attacks all lifecycle stages of a broad range of honeybees. At present, $V$. destructor is the greatest threat for apiculture (Rosenkranz, Aumeier, \& Ziegelmann, 2010). The species sucks the blood from both the adults and the developing brood, weakening and shortening the life span of bees upon which they feed. Untreated infestations will destroy entire honeybee colonies. Although $V$. destructor can only reproduce on honeybees, other insects may also assist in spreading it.

(13) The Chinese mitten crab (Eriocheir sinensis) is native to eastern Asia. It first appeared in Europe in the early 20th century. The species has spread via ballast water and intentional introduction to Continental Europe and the UK, Southern France and the USA (Dittel \& Epifanio, 2009). The negative impacts of E. sinensis include competition with native species, predation, increased river bank damage through its burrowing activities, and clogging of commercial water intakes. Methods to minimize future spread are quite limited once the species is introduced (Gollasch, 2011). It is thus important not only to manage the existing populations but also to prevent them from being introduced and spread out further. Management measures could include its consumption as a source of food or animal feed (European Commission, 2017).

\section{http://www.ejmste.com}

